\title{
Causes and Consequences of Child work in Brick Field: A Study on the Selected Brick Fields in Char Bhadrasan under Faridpur District.
}

\author{
${ }^{1}$ Masud Rana, ${ }^{2}$ Amita Das \\ ${ }^{1,2}$ Lecturer, Department of Human Resource Management, Jatiya Kabi Kazi Nuzrul Islam University \\ Trishal, Mymensingh,Bangladesh
}

\begin{abstract}
Social norms and economic realities mean that child labor is widely accepted and very common in Bangladesh. Many families rely on the income generated by their children for survival, so child labor is often highly valued. Additionally, employers often prefer to employ children because they are cheaper and considered to be more compliant and obedient than adults. When children are forced to work, they are often denied their rights to education, leisure and play.

Studies revealed that one in every six children in Bangladesh was working children. The gravity of the situation led our initiative to study on child labour in brick field in the work area in Char Bhadrasan under Faridpur district .This study uses data to examine the different components of child labor in brick field. Study used quantitative method for data collection and particularly survey was used. A total of 103 respondents of five brick fields in Char Bhadrasan upozila were interviewed. SPSS windows program was used to process and organize the data for the study. The respondent were interviewed regarding various aspects related to the child labour in brick field includes causes and consequences of child labor to engage their risky job, working environment, their schooling profile, their future goal etc.

The fieldwork observation shows that the working environment in brick field are hazardous to child health due to unsanitary environment, unsafe working environment (such as heat, burning ashes, flying ashes, and pieces of broken bricks everywhere), and the hazardous work (prolonged working hours, heavy work, and dangerous jobs).They also suffer from breathing problem, cold \& fever, minor injuries and sometime more than that.
\end{abstract}

Inspire of that majority of child workers have a very common expectation that is all of them want to lead a happy life with their work and their family.

Keywords: Child labor, working environment, instrument development, Gender, Awareness, Bangladesh.

\section{Introduction}

The Child Labour issue is one of the great concerns throughout the world. It is quite common for children of all types of societies to be engaged in some forms of occupation depending on the economic structure and level of development. As such, the phenomenon is not connected to any particular country or culture. In fact, Child Labour has been generally received more as a problem of poor developing countries like Bangladesh as well as our ability which is consistently facing Challenges against poverty, high population growth, rising employment, natural disaster and so on. Child labor, a sheer reality in Bangladesh like many other developing countries, is one of the major socio-economic problems in the country.

\section{Operational definition}

In this study researcher use child labour as a concept that, those children are called child labour who work for money to maintain their livelihood as well as to support their family economically and those worker researcher selected as respondent who has been working since at least one month and aged between 5-17 in this study area (brick field in Char Bhadrasan under Faridpur district.) The study tried to find out what are the causes behind engaging children such risky work and its consequences.

\section{Rationale of the study}

Topic of this research is child labor in brick field: causes and consequences. The researchers has tried to reveal the various form or hidden issues rested to child work as a common social problem in our locality. It affects the life of children and the child development.

In fact of the country concerned child labour has been generally perceived as a problem of poor developing countries as Bangladesh. So researcher selected this study about the concerning issue with a hope of child development and eliminating the worst form of child worker in brickfields and save their future life. 


\section{Objectives of the Study}

The overall objective of the study is to understand the causes and consequences of child labor in brick field and for this purpose the study incorporates with some specific objectives that are stated below:

\section{Specific objectives:}

- To explore the reasons for engaging children in a risky environment like brick field.

- To state the working and living conditions of the children in the brick field.

- To identify the conditions of harassment that child workers face.

- To unearth the consequences of being engaged in brick field.

\section{Methodology}

A methodology refers to the choices researcher make about the cases to study methods of data gathering, forms of data analysis etc. in planning and executing a research study (Silverman, 2001:4). While it directs how a researcher will go about studying phenomenon, in this research. a detailed design of the study including sample size, study population, process of survey instrument development, data collection and data analysis, ethical consideration etc. will be explained in order to achieve an insight about of the whole procedure of this research work.

\subsection{Study population}

Before selecting a sample size a researcher has to demarcate a population. "Population is the total group of people who meets certain criteria of interest to the researcher is called population the population" (lin, 1976:146). In this study population is consisted of the children who work in the brick fields in Char Bhadrasan under Faridpur district.

\subsection{Selection of the Study Area}

In the present study Char Bhadrasan Upzila under Faridpur district had been identified as the study area.

\subsection{Sampling technique and sample size}

Considering a non probability sampling procedure data were collected purposively from the respondents who are available during the survey. Though there was defined target population but the researcher was not able to carry out a research using probability sampling technique. A semi-structured survey was served as the main data collection method for this study. "A subset of cases from the population chosen to represent is called a sample". (Lin, 1976:146) A total 103 sample were taken from the different 9 brick fields of Char Bhadrasan Upzila in Faridpur district.

\begin{tabular}{|l|l|l|}
\hline & Frequency & Percent \\
\hline Male & 80 & 78 \\
\hline Female & 23 & 22 \\
\hline Total & 103 & 100 \\
\hline
\end{tabular}

\subsection{Survey instrument}

Survey was the main data collection method of this study. A semi-structured survey was conducted to collect necessary primary data from the target population. For conducting survey, a semi-structured questionnaire was used.

\subsection{Construction of the Questionnaire}

The questionnaire contains 31 questions. The questionnaire is finally drafted based on a compromise between the requirement and ability of the respondents to furnish the data, while designing the questionnaire certain statistical and operational factors among which the terms of data sought, the method of collection, the respondents units processing and tabulating requirement also considered.

\subsection{Data collection procedures}

To conduct the survey a semi structured and self-employed questionnaire has been used containing pertinent questions in relation to the objectives of the study. 


\subsection{Data Processing and analysis}

In this study data collected from field were edited to look for a missing or error, codified and to entry into the computer and grouped in terms of variables the statistical Package for the Social Sciences (SPSS) version 18.0 was to analyze the data.

\section{Limitations of the study}

Research is a complex, complicated and scrutinizing activity based on scientific knowledge and competence. For doing the study a lot of problems are suffered by the researcher's. Some of these problems are given below:

- The fieldwork was limited only Char Bhadrasan in Faridpur. The study sample size is very precise.

- Most of the sample respondents are illiterate or less illiterate. So, due to this reason, proper and adequate answer could not be taken from the respondents against questionnaires.

- To prepare an analytical study, financial assistance is most necessary. Lack of sufficient money, various types of analysis did not possible.

\section{Review of literature}

As stated in Emerson and Knabb (2007), there has recently been renewed interest in this topic among economists, which has led to a series of theoretical studies with the aim of better understanding the causes and consequences of child labor and to help guide appropriate policy responses. There are now close to 100 publications that address child labor issues in Bangladesh. About 30 of them are multi-country data surveys of international or national agencies, like the various surveys of the International Labor Organization and the annual surveys of the United States Department of Labor's findings on the worst forms of child labor. At least six publications locus on South Asia, addressing (i) the linkage between child labor and trade (Sharma, 2007). (ii) Child labor and child abuse (Bhattacharya, 2007), (iii) domestic and international initiatives to reduce child labor (Castle, Chaudhri and Nyland, 2002), and (iv) the linkages between child labor and educational issues (Kabeer, 2001; Kabeer, Nambissan and Subrahmanian, 2002; and Ray, 2001).

The most relevant for this study is that of Kabeer (2001), who explores the geographical, economic and social dimensions of the twin problems of child labor and poor educational outcomes in India and Bangladesh. She comes to the conclusion that poverty is not necessarily barrier to accessing educational services and that there is a need to draw out the lessons from the $\bullet$ efforts of the few educational planners who have (i) understood the patterns of disadvantage caused by caste, gender, ethnicity and livelihood insecurity and (ii) started delivering educational services geared to the needs of the marginalized.

Of the about 60 publications that focus exclusively on child labor in Bangladesh, about20 have been published before 2000 and about 40 have been published since 2000. Among the 40 more recent publications, seven address legal issues (Ali, 2004; Habib,2008; Hasan, 2008; Murshed, 2001; Ruwanpura and Roncolato, 2006; Siddiqua, 2004; and Siddiqui, 2001), coming to the conclusion that the main problem is not related to the shortcomings of labor laws in Bangladesh but their enforcement. Eight studies focus on child labor and educational issues (Amin. Quayes and Rives,2006a, Ehsan, 2001, Khanam, 2008; Khanam and Ross, 2005; Nath and Hadi, 2000;Ravallion and Wodon, 2000; Shafiq, 2007a; and Shafiq, 2007b).

The overall conclusion that can be drawn from these studies is that child labor is a deterrent to schooling as well as that the poor education system encourages children to work. The remaining recent child labor studies address a variety of socio-economic issues, trends and policy options.

Most important studies that have been published since 2006 in alphabetical order. Ali (2006) examines the nature and extent of child labor, and contemplates the factors influencing participation in child labor, based on a comparison between the National Child Labour Survey 1995-96 and 2002-03. He observes that there have been significant changes in some important aspects of child population occupational choice, rural urban differentials, schooling options, etc.) in the country and their participation in the workforce.

$\mathrm{He}$ also observes that higher proportion of child labor comes from land poor and the poorest households and concludes that household's education and occupational choice also matter for child labor. Amin, Quayes and Rives (2006b) show that for market work, fathers and children may be substitutes or complements in supplying labor, whereas mothers and children am complements for all groups of children. They also find almost no connections between parent3' market work and dauaters' household work status.

Emerson and Knabb (2007) show that the lack of access to capital markets gives rise to a Paretoinferior outcome that is characterized by the presence of child labor and a low level of hurnat capital. Based on a child labor model in a dynamic, general equilibrium setting, they show that a pay-as-you-go social security program can move the economy out of this inferior equilibrium by allowing families to redirect household 
income. They also show that the effectiveness of the intergenerational transfer program relies critically on its ability to change the behavior of households through their expectations. Kalam (2007) has looked at a variety of child labor issues based on a survey in the Dhaka City Corporation, which provides findings on important differentials of the child labor, like, for example, the causes of child labor. He concludes that child labor cannot be completely eliminated unless Bangladesh's economy is developed sufficiently to create job opportunities for the' vast majority of its adult work force and that poverty alleviation is a pre-condition to elimination or at least minimization of child labor. Given the chronic economic issue of child labor in Bangladesh, it cannot be stopped simply by a piece of legislation. Instead, it can be eliminated only by adoption of suitable long term economic measures that eliminate the need for child labor.

Khanam (2006) found that the trend and incidence of child labor has been increasing in Bangladesh even though child labor is on a declining trend in other South Asian countries, which she explains with the irrelevance or inadequacy of existing child labor laws in Bangladesh. This study suggests that a combination of policies would be appropriate for reducing child labor, which include employment generation schemes that lead to economic prosperity for the household, compulsory schooling for children, school enrolment subsidy, improving school infrastructure, the quality of education, flexibility in school schedules and adult literacy campaigns that increase community or social awareness, especially of the adult female.Mamun, Mondal. Islam and Kabir (2008) aim at investigating the factors that influence the health complications of the child laborers by collecting primary data from some selected areas of Faridpur district, Bangladesh.

Their logistic regression analysis shows that working hour per day, place of work and age at the time of entrance to work appeared to be the most significant factors in determining the likelihood of facing health complications.

They find that (i) an increase in working hours increased the likelihood of health complications. (ii) children working in more hazardous sectors face more health problems than those working in comparatively less hazardous sectors, and (iii) children that enter into work at an early age face more health comp k at an older aue.13ased on fieldwork that was carried out during July-September 2044, Sumon (2007) provides an in-depth picture of child labor in the automobile sector. He found that a significant number of children work in the automobile sector and that almost all children came from the poorest families in rural areas. He also found that children worked for very low salaries and were sometimes only given food in return for their labor. They were furthermore exposed to all types of child exploitation and various hazards. Based on the analysis of secondary sources, the study also suggests that (i) there 5 has been an alarming increase in hazardous child labor in recent years, (ii) coercive measures to stop child labor would result in forcing the poorest families to engage their children in underground activities such as prostitution, terrorism, robbery and hijacking; and (iii) that integrated policy actions can quickly improve the working environment of child laborers. Tariquzzaman and Hossain (2009) come to the conclusion that poor boys have been left behind by public policy efforts to expand school access in Bangladesh — the same policies which have succeeded in attracting girls to school.

They draw on original research to explore the failure to tackle the exclusion of poor boys from school, arguing that paid work has become more attractive in a context in which education is of poor quality and there are no social sanctions against child labor. They also states that poor boys may not necessarily inherit deeper poverty as long as there is steady economic growth, but that they are likely to inherit a position at the lower end of the social scale in the absence of state or social sanctions against child labor.

Tariquzzaman and Kaiser (2008) aimed at analyzing how and what factors have contributed in changing the patterns and perspectives of child labor over the last 15 years. Based on an in-depth research of 120 child laborers and 40 employers of child labor in a Dhaka slum and a rural community in the poor northern district of Nilphamari they articulate the employers' perspectives on child labor, with particular emphasis on understanding what factors have caused them to change their own practices over time. In this regard, they address four main issues: (i) why employers depend on child labor; (ii) how the types and forms of children's employment are believed to have changed over the last 15 years; (iii) factors that employers believe have contributed to these changes; and (iv) how employers are adapting to the changing situation respect to the employment of children. Source: Bangladesh Development Research Working Paper Series (BDRWPS) BDRWPS No. 8 (July 2009)

\section{Theoretical framework of the study}

The theoretical framework adopted in this study is a household production model introduccd by Becker (1965) and later developed De Tray (1973), Rosenzweig and Evenson (1977). Rosenzweig and Evenson (1977) adopt a household production function to study the multiple activities of children in a developing country. Subsequently, Ridao- Cano (2001), Emerson and Portela (2001) adopt the same approach in a collective bargaining framework to examine the child time allocation to work and school. Continuing in this tradition and motivated by the Becker-type household models, Researcher use a general utility maximizing framework to 
model the choices of child's school and activities as a reduced-form function of individual, household, Parental and community characteristics.

The assumption here that children are not making their own choices independently. Rather children are under control of their parents. Hence any decision regarding whether a child will work or study can be well explained by a model of parental decisions. Parents value the current consumption of the household as well as the human capital attainment of the children. However there is a trade off between current consumption (which is gained by engaging the children in productive activities) and human capital accumulation (child's schooling). If a child is engaged in working, it receives less education, which determines fewer earnings in future. The human capital accumulation of the children is the increasing function of schooling. A child can go to school full time or can work full time or can combine work and school or can do neither work nor study. However, what a child will do that will be determined by parents.

The chosen theories for the study are taken from the book "What Works for Working Children-by Boyden J, Ling B, Myers W. The book is based on upon published and unpublished literature for researchers dealing with the subject of child labour. The book deals with the child perspective and considers what is best for the child as the most important consideration of all. The authors aim to put the children and their best interests in the centre of the picture, that together with data from field studies and surveys from Swedish Save the Children and other international Non-governmental organizations make the book a useful source of information. The theories stated in the book cannot be recognized to be the only existing but through findings in other sources, these theories are clearly suitable for this study.

\section{Child labour as a contribution to the family}

According to the theory of child labour as a contribution to the family, most children in developing countries work because they want to support their families. Studies done by Save the Children Sweden show that most children start to work on command or at least by a request from their family. In many cases children work simply for the reason that they are told to, some voluntary and some against their will.

Boyden J, Ling B and Myers W points out in this theory results from studies made in Indonesia and Morocco which show that many children prefer factory work instead of work inside the household. The reason is that they find household work more grinding and futureless. Many children also get a good feeling when they can help their families economically; a fact received from an Ethiopian study, where the children answered that the feeling to be able to contribute to their families' monetary situation was the thing they liked most with work. A survey among street children in Brazil showed that the children lived in the streets because they wanted to help their mothers. The largest part of their earnings was given to their family weekly. The fear of losing support from the family and being left alone is another common factor behind child labour. Boyden J, Ling B and Myers $\mathrm{W}$ claim that an underlying fear of abandonment often exist among working children. Children working in urban slums are often personally acquainted with other children in the same situation; it seems to be important for children to get the feeling of close family ties, even if it is not their "real" family. The enforcement of standards concerning minimum age for work has been seen by many children as a threat to their will of contributing to their families and to have an income. The children feel they have the right to work because they must satisfy their basic needs and thereby defend their own survival.

\section{Child labour as a means of self-actualization}

The principal argument of this theory is that many children would want to work even if they did not have to. Even if poverty were non-existing and nowhere were children obliged to work, some children still would like to take part in productive work. For the same reason as many middle-class children seek part-time work in industrialized countries, the children in developing countries want to work. The ILO declares that work is an essential part of life, i.e. a way to participate in the society and the economy. Non-exploitive work makes children feel more mature, independent and included in the society at large. Many children also believe that work is a good way for them to get education and thus become competent and prosperous adults.

\section{Child labour as a consequence of family-dynamics}

The third theory stated by Boyden J, Ling B and Myers W is the explanation of child labour, as result of inadequate family decision-making or relationships. Child labour can be seen to represent errors either in families' view of reality or in their strategic thinking about how to best deal with that reality. An example is the idea that most parents who let their children work instead of being in school are ignorant of the importance of education. If those parents would have a known what a great outcome education can give, they would have tried to keep their children in school. The family dynamics explanation often blames these moral judgments: child labour can be a consequence of a breakdown in family values in which they do not fulfill their protective function. A breakdown in values is, for example, when parents sell their children into prostitution or bondage 
with the purpose of material benefit, for example a wedding. This theory also claims that child labour can be a result of ignorant and irresponsible parents.

The World Bank among others has emphasized the relationship between household size and the prevalence of child labour among poor populations in developing countries. A common finding is that children from large households are more likely to be involved in child labour than children from small households. Children from large households are therefore more likely to get involved in child labour. Not all children in the same household are deprived equally. Many societies send their boys to school, not the girls and the older siblings are more likely to be sent to work than the working ones. Education and occupation of the parents is another important factor behind child labour. The more education parents, particularly mothers, have the less likely they are to let their children work. A common debate is about whether poor families have children as a strategy to provide more workforces. Families with labour intensive occupations, such as farmers, arc more likely to have many children. When children start to participate economically from an early age, their income from labour exceeds with the costs of raising them

\section{Child labour as a result of poverty}

Child labour as a result of poverty is one of the most common theories about the causes behind underage work. A majority of studies in developing countries show that poor families put their children in child labour more often than families in a better economic situation. Increase of the household income is one reason but it is also a safety strategy to even out the risk of losing economic income, for example with the loss of an adult income earner or a failed harvest. According to ILO child labour commonly may represent around 20 per cent of the household income, and as poor families spend the majority of its income on food, consequently the children's incomes are crucial. In many households not all income is equally allocated to meet basic needs. Income earned by the mother of the household is more likely to be available for the family than income earned by the father. Children's earnings given to mothers may therefore be more important for the family than the earnings gained by the father. It is common that children think about such factors, they are fully aware of their work as an important part to support their family. Boyden J, Ling B, and Myers W indicate that the fundamental importance of child labour as 3 result of poverty is so widely accepted and well demonstrated that there is no need to question the theory. But, there exist disagreements about to what degree poverty is fundamental to child labour - if poverty was the sole determinant for child labour, the highest rates of child labour would be found in the poorest parts of the world. This is not always the case. The relationship between child labour and poverty is varied, vague and indirect. If poverty would be the only determinant, the same patterns would be found over the world, but they are not. In rich countries it is often the opposite; children from high-income families are more likely to work.

The finding was that children in the wealthier south were much more likely to be involved in labour than were the children in the poorer north. The best explanation was that the well-situated environment in south provided more labour opportunities for children. Even if more children might have been looking for work in the northern poor area they could not find it.

\section{Conceptual Framework}

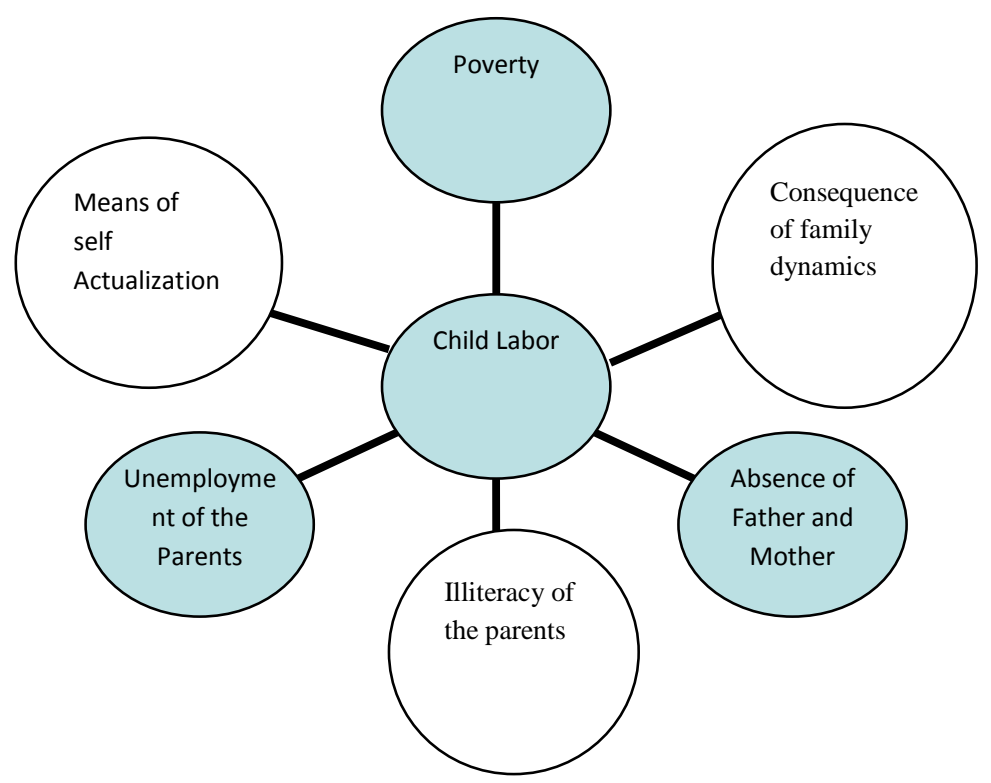




\section{Analysis and Findings}

Child labour has become one of the social issues in Bangladesh. One concern is that work undertaken by children in brick-making factories is by nature heavy and dangerous, coupled with long working hours, school interference, and low payment Thus, its far reaching effect on child development, especially on schooling and health, is devastating. Yet some parents still sent their children to work in brick factories and hiring children to work in brick factories is suspected to continue by many employers.

\subsection{Schooling Profile of Child Workers}

Many child workers in brick-making factories were not in school About three fourths of them quitted school more than two years with several reasons, including family reasons (the family economic hardship, their needed labour by parents, sick parents, and family debt. It is evident that about $95.1 \%$ child worker reported that they don't go to school. And 4.9\% respondents don't answer. They said that their parents are not able to give them school expenditure although cost is very low. Then they said who will provide their need if they go school because most of the family even depend of their child income.

\subsection{Work Profile of the Child Interviewees}

Child workers in brick factories usually performed multiple tasks. Common tasks are Mixing clay, cutting raw brick. Digging clay, loading bricks in and out of the kiln, loadings brick onto the truck, and arranging bricks to dry. However, most children work full-time in brick factories 6-8 hours per day (85.4\% fig: 12). The average wage is $(54.4 \%) 2000-3000$ tk per month.

\subsection{Reasons for engaging this risky work.}

According to children's responses (Figure 16), top reasons for working are the family economic hardship. And most of the time they spent money for their family \&personal need. They work most of the time as a contributor of the family sometimes as means of self actualization. As a consequence of family dynamics and most of the important pull factors is that poverty leads them to work.

\subsection{Work Conditions in Brick Field}

The fieldwork observation shows that the working environment in the brick factory is hazardous to child health due to unsanitary environment (unclean, smoke, bad smells of manures, and consuming pond water), unsafe working environment (such as heat, burning ashes, flying ashes, and pieces of broken bricks everywhere), and the hazardous work (prolonged working 110 heavy work, and dangerous jobs).

\subsection{Work Safety and Regulations}

According to child workers, many brick factories do not have any work regulations or safety measures. And most of the brick field (85.4) \% has no safety materials. Only (9.7) \% respondents report that they use safety materials during their work. The tasks include operating a brick machine, cutting raw bricks, and mixing clays, carrying clays etc.

\subsection{Impact of Child Labour}

In terms of specific health problems frequently experienced. According to table (22\&25), the respondent report that about (55.3\%) their work is the cause for their disease. Sometimes they have to face different injuries. They also suffer from breathing problem, cold and fever and sometimes more than that In addition, nearly one half (62)\% of the child workers had minor injuries due to work.

\subsection{Expectations for the Future of Child Workers}

The majority of child workers do not want to continue their schooling, contrary to the expectation of parents, especially parents who lived in brick factories. This may be due to the fact many child workers interviewed had already quitted school. Most of the worker wants that they could carry out the bear both of their family and them. They also want that their working condition would be easier and safety for them. And very common expectation is that all of them want to lead a happy life with their work and their family.

\section{Recommendations}

1. Educational program should enhance so that every student get educational opportunity. For that formal and non formal education through part time \& full time school, vocational training activities may be enhanced.

2. Govemment should take action to strictly enforce measure to stop child labour \& take step to end Percent once children education. Different NGO can co-operate with government; for implementation their expectation. 
3. Since the main reason for children to work is the family economic hardship, it may be unwise to eliminate all forms of child labour. However, children should be prohibited from undertaking all dangerous jobs, including operating brick machines, brick firing operations, and clay preparations. In addition, work-load and work-age regulations should set and strictly enforced.

4. Motivational publicity \& campaign should be increased so that the parents of the children realize the better future of their children then to engage their child in risky work.

5. Efforts should aim at developing the public awareness of children's rights and the damage to children caused by child labour.

6. As extreme poverty compels children to go to work, so the policy maker should take action that would reduce pressure of poverty in poor household.

7. Educational facilities, different vocational training facilities should be free for the poor children.

\section{Conclusion}

Child labor have become a sheer reality in Bangladesh like many other developing countries, is one of the major socio-economic problems in the country. The working children, as a socio-economic group, happened to be the most disadvantaged because for survival of self and family. They are forced to work for living, sacrificing their childhood along with their future. They are generally not getting medical services, many times not even in cases of workplace accidents. It is common for all children in brick field to suffer from illness frequently with cold fever, skin diseases, physical pain, and eye-sight-related problems. Children, with the compulsion of taking up work at early age do not get the proper supporting environment for their physical and mental development. Many working children, especially girls, are also subjected to sexual abuse and harassment. Since the main reason for children to work is the family economic hardship, it may be unwise to eliminate all forms of child labour. However, children should be prohibited from undertaking all dangerous jobs, including operating brick machines, brick firing operations, and clay preparations. In addition, work-load and work-age regulations should set and strictly enforced. And work safety regulations should be set and standardized for all brick factories. The legal force should be given to the regulations. The regulations should list also safety measure requirements for all child workers, including safe working environment and use of protection devices that include safety helmet. Working shoes, workable gloves, masks, and protecting glass.

\section{References}

[1] Ali, Zulkar (2006) "Do Child Labourers Come from the Poorest? Evidence from NCLS and 64-Village Census Plus" Dhaka, Bangladesh: Bangladesh Institute of Development Studies (BIDS), Programme for Research on Chronic Poverty in Bangladesh (PRCPB) Working Paper No. 11 (February).

[2] Amin, Shahina; M. Shakil Quayes; and Janet M. Rives (2004) "Poverty and Other Determinants of Child Labor in Bangladesh", Southern Economic Journal, Vol. 70, No. 4 (April),

[3] Amin, Shahina; Shakil Quayes; and Janet M. Rives (2006a) "Market Work and Household Work as Deterrents to Schooling in Bangladesh", World Development, Vol. 34, No. 7 (July),

[4] Amin, Shahina; Shakil Quayes; and Janet M. Rives (2006b) "Arc Children and Parents Substitutes or Complements in the Family Labor Supply Decision in Bangladesh?", The Journal of Developing Areas, Vol. 40, No. 1 (Fall), pp. 15-37.

[5] Basu, Kaushik (1999) "International Labor Standards and Child Labor" Challenge, Vol. 42, No. 5 (September - October), pp. 80-93;

[6] Basu. Kaushik and Zafiris Tzannatos (2003) "The Global Child Labor Problem: What Do We Know and What Can We Do?" World Bank Economic Review, Vol. 17. pp. 147-173.

[7] Bhattacharya, M. S. (2007) Saga of Agony and Shame: Child Labour and Child Abuse in India and SAARC Countries (New Delhi, India: Decent Books).

[8] Cain, Mead (1978) "The Household Life Cycle and Economic Mobility in Rural Bangladesh", Population and Development Review, Vol. 4, No. 3 (September). pp. 421-438.

[9] Castle, R.; Chaudhri, D. P.; and C. Nyland (2002) "Child Labour in South Asia: Domestic and International Initiatives Including ILO and WTO", Indian Journal of Labour Economics, Vol. 45, No. 3 (July-September), pp. 497-516.14

[10] Ehsan, Khaled (2001) "Children and Education", in: Shishu Adhikar Sangjog (ed.) Child Rights: Reality and C'hallenges (Dhaka, Bangladesh: British Council)

[11] Emerson, Patrick M. and Shawn D. Knabb (2007) "Fiscal Policy, Expeciation Traps, and Child Labor", Economic Inquiry, Vol. 45, No. 3, pp. 453-469. Grant, James P. (1993) All for Children (New Delhi, India: United Nations Children's Emergency Fund (UNICEF)).

[12] Habib, Murshida Ferdous Binte (2008) "Child Rights and Child Labour in Bangladesh"Paper presented at the 29th International Congress of Psychology, Berlin, Germany (July 20-25).

[13] Hasan, Jesmul (2007) "An Overview of Child Labour Laws, Prevention Strategies and Assessment of Their Effectiveness in Bangladesh", in: Gamini Herath and Kishor Sharma (eds.) Child Labour in South Asia (Burlington, VT, USA: Ashgate).

[14] Kabeer, Naila (2001) "Deprivation, Discrimination and Delivery: Competing Explanations for Child Labour and Educational Failure in South Asia", Brighton, UK: University of Sussex, Institute of Development Studies (IDS), IDS Working Papers, No. 135 (May.

[15] Kabcer, Naila: Geetha B. Nambissan; and Ramya Subrahmanian (2002) Child Labour and the Right to Education in South Asia: Needs versus Rights? (Thousand Oaks. CA, USA: Sage Publications).

[16] Kalam, Iftekhar M. Shafiqul (2007) "Glimpse on Child Labor: A Study on Child Labor Situation in Dhaka City Corporation Area", BRAC University Journal, Vol. 4, No. 1, pp. 19-29.

[17] Khair, Surnaiya (2005) Child Labour in Bangladesh: A Forward Looking Policy Study (Geneva, Switzerland: International Labor Office, April) 
[18] Khanam, Rasheda (2006) "Child Labour in Bangladesh: Trends, Patterns and Policy Options" Asian Profile, Vol. 34, No. 6, pp. 593-608.

[19] Khanam, Rasheda (2008) "Child Labour and School Attendance: Evidence from Bangladesh", International Journal of Social Economics, Vol. 35, No. 1-2, pp. 77-98

[20] Khanam, Rasheda and Russell Ross (2005) "Child Work and Other Determinants of School Attendance and School Attainment in Bangladesh", Munich, Germany: Munich Personal RePEc Archive (MPRA), Paper No. 9397.

[21] Mamun, Rashed; Nazrul Islam Mondal; Rafiqul Islam; and M. Kabir (2008) "Impact of Some Key Factors on Health Complication of the Child Laborers during Work: A Study on Rangpur, Bangladesh", Pakistan Journal of Social Sciences, Vol. 5, No. 3, pp. 262267.15

[22] Murshed, Madiha (2001) "Unraveling Child Labor and Labor Legislation", ournal of International Affairs, Vol. 55, No. 1 (Fall), pp. 169-189.

[23] Nath, Samir R. and Abdullahel Hadi (2000) "Role of Education in Reducing Child Labour: Evidence from Rural Bangladesh", Journal of Biosocial Science, Vol. 32, No. 3, pp. 301-313.

[24] shafiq, M. Najecb (2007a) "Household Rates of Return to Education in Rural angladesh: Accounting for Direct Costs, Child Labour, and Option Value", Education Economics, Vol. 15, No. 3, pp. 343-358.

[25] Shafiq, M. Najeeb (2007b) "Household Schooling and Child Labor Decisions in Rural Bangladesh", Journal of Asian Economics. Vol. 18, No. 6 (December), pp. 946-966.

[26] Sumon, A. I. (2007) "Informal Economy in Dhaka City-Automobile Workshop and Hazardous Child Labor", Pakistan Journal of Social Sciences, Vol. 4, No. 6, pp.711-720.

[27] Tariquzzaman. Sheikh and Naomi Hossain (2009) "The Boys Left Behind: Where Public Policy has Failed to Prevent Child Labour in Bangladesh", /DS Bulletin, Vol. 40, No. 1. pp. 31-37.

[28] Tariquzzaman, Sk. and Elma Kaiser (2008) "Employers' Perceptions of Changing Child Labour Practices in Bangladesh", Dhaka, Bangladesh: BRAC Monograph Series

[29] Bangladesh Development Research Working Paper Series (BDRWPS) BDRWPS No. 8 (July 2009)

\section{APPENDIX:}

Table No1: Distribution of the respondents by Gender

\begin{tabular}{|l|l|l|}
\hline & Frequency & Percent \\
\hline Male & 80 & 78 \\
\hline Female & 23 & 22 \\
\hline Total & 103 & 100 \\
\hline
\end{tabular}

From the table above, it is clearly evident that 78 of the respondents are male and 22 of the respondents are found to be female.

Table No 2: Distribution of the respondents by the number of sibling.

\begin{tabular}{|l|l|l|}
\hline Age & Frequency & Percent \\
\hline $3-4$ & 90 & 87 \\
\hline Above 4 & 13 & 13 \\
\hline Total & 103 & 100 \\
\hline
\end{tabular}

The table shows that most of the child labours (87) have more then 3 to 4 sibling'. And 13 percent children have more than 4 siblings.

Table No 3: Distribution of the respondents by their birth order.

\begin{tabular}{|l|l|l|}
\hline & Frequency & Percent \\
\hline $1^{\text {st }}$ & 31 & 30 \\
\hline $2^{\text {nd }}$ & 26 & 25 \\
\hline $3^{\text {rd }}$ & 25 & 24 \\
\hline $4^{\text {th }}$ & 21 & 21 \\
\hline Total & 100 & 100 \\
\hline
\end{tabular}

From the above table it is evident that the highest number of child workers $30 \%$ is the first child of their parents and $21 \%$ is the $4^{\text {th }}$ place.

Table NO 4: Distribution of the respondents by their parent's aliveness.

\begin{tabular}{|l|l|l|}
\hline \multicolumn{1}{|l|}{ Frequency } & Percent \\
\hline Yes & 40 & 39 \\
\hline No & 3 & 3 \\
\hline Only father alive & 18 & 18 \\
\hline Only mother alive & 42 & 41 \\
\hline Total & 103 & 100 \\
\hline
\end{tabular}

In the above table it is evident that $41 \%$ child worker has no father .but only $3 \%$ has no parents $\&$ $38.8 \%$ has both father and mother. 
Causes and Consequences of Child work in Brick Field: A Study on the Selected Brick Field in Char Bhadrasan under Faridpur District.

Table NO 5: profile of the respondents by with whom do they live.

\begin{tabular}{|l|l|l|}
\hline & Frequency & Percent \\
\hline Biological father /mother & 82 & 80 \\
\hline Step father/mother & 18 & 18 \\
\hline Total & 100 & 97 \\
\hline Unanswered & 3 & 3 \\
\hline Total & 103 & 100 \\
\hline
\end{tabular}

From the above table, highest number of child worker $80 \%$ live with their biological father and mother .and $18 \%$ live with their step father or mother.

Table NO 6: Distribution of the respondents by their father occupation.

\begin{tabular}{|l|l|l|}
\hline & Frequency & Percent \\
\hline Day labour & 27 & 26 \\
\hline Rickshaw puller & 21 & 20 \\
\hline Unemployed & 5 & 5 \\
\hline Died before & 50 & 49 \\
\hline Total & 103 & 100 \\
\hline
\end{tabular}

Above table shows that the highest $26 \%$ parents of the child worker are day labour \& $5 \%$ is unemployed.

Table No 7: Distribution of the respondents by their mother occupation.

\begin{tabular}{|l|l|l|}
\hline & Frequency & Percent \\
\hline House wife & 47 & 46 \\
\hline Day labour & 16 & 16 \\
\hline Others & 32 & 31 \\
\hline Diet & 8 & 7 \\
\hline Total & 103 & 100 \\
\hline
\end{tabular}

A significant number of numbers of respondents from the above table state that $46 \%$ mothers of the child labour are housewife \& $31 \%$ are engaged in different work.

Table No 8: Distribution of the respondents by the family member who work in the brick field.

\begin{tabular}{|l|l|l|}
\hline & Frequency & Percent \\
\hline Yes & 73 & 71 \\
\hline No & 30 & 29 \\
\hline Total & 103 & 100 \\
\hline
\end{tabular}

Table No 9: Distribution of the respondents by the family member who work with them.

\begin{tabular}{|l|l|l|}
\hline & Frequency & Percent \\
\hline Father & 8 & 8 \\
\hline Sister & 5 & 5 \\
\hline Brother & 47 & 46 \\
\hline Others relative & 13 & 13 \\
\hline Unanswered & 30 & 29 \\
\hline Total & 103 & 100 \\
\hline
\end{tabular}

From the above table highest $71 \%$ respondent has family member the work with them.

Table No 10: Distribution of the respondents by the work they under take in the brick field.

\begin{tabular}{|l|l|l|}
\hline & Frequency & Percent \\
\hline Operating a brick-making machine & 25 & 24 \\
\hline Cutting Digging & 11 & 11 \\
\hline Digging & 5 & 5 \\
\hline Carrying clay & 21 & 20 \\
\hline Mixing Clay & 30 & 29 \\
\hline Loading bricks on to the trucks & 3 & 3 \\
\hline Arranging bricks to dry & 8 & 8 \\
\hline Total & 103 & 100 \\
\hline
\end{tabular}

is evident from the above table the highest $29 \%$ child worker engage with mixing clay in the brick field and only $3 \%$ worker loading bricks on the truck and significant number operating brick-making machine. 
Causes and Consequences of Child work in Brick Field: A Study on the Selected Brick Field in Char Bhadrasan under Faridpur District.

Table No 11: Distribution of the respondents by their working hour.

\begin{tabular}{|l|l|l|}
\hline & Frequency & Percent \\
\hline $6-8$ hrs per day & 88 & 85 \\
\hline $9-10$ hrs per day & 15 & 15 \\
\hline Total & 103 & 100 \\
\hline
\end{tabular}

Table shows that $85 \%$ Respondent work 6-8 hours per day and no one work more than 10 hour.

Table No 12: Distribution of the respondents by their mode of salary.

\begin{tabular}{|l|l|l|}
\hline & Frequency & Percent \\
\hline Daily & 49 & 48 \\
\hline Monthly & 54 & 52 \\
\hline Total & 103 & 100 \\
\hline
\end{tabular}

From the above table 52\%getting salary monthly and $48 \%$ get salary daily.

Table No 13: Categories of the respondents by money they get per month.

\begin{tabular}{|l|l|l|}
\hline & Frequency & Percent \\
\hline $2000-3000$ tk & 56 & 54 \\
\hline $4000-5000$ tk & 34 & 33 \\
\hline 6000 -above tk & 13 & 13 \\
\hline Total & 103 & 100 \\
\hline
\end{tabular}

From the above table 55\% respondent reported that they get 2000-3000 tk per month and only $13 \%$ get more than 6000tk.

Table No 14: Respondents opinion about what they do by their earned month.

\begin{tabular}{|l|l|l|}
\hline & Frequency & Percent \\
\hline Use of personal need & 3 & 3 \\
\hline Use of family needs & 34 & 33 \\
\hline Both & 66 & 64 \\
\hline Total & 103 & 100 \\
\hline
\end{tabular}

Above table shows those $64 \%$ child workers spend money both for their personal and family need.

Table No 15: Respondent opinion about the causes of engaging the work.

\begin{tabular}{|l|l|l|}
\hline & Frequency & Percent \\
\hline Economic hardship & 88 & 85 \\
\hline Personal needs & 15 & 15 \\
\hline Total & 103 & 100 \\
\hline
\end{tabular}

A significant number of respondents from above table state that $85 \%$ have to do this work for economic hardship.

Table No 16: Respondent's opinion whether they forced to do the work or not.

\begin{tabular}{|l|l|l|}
\hline & Frequency & Percent \\
\hline Yes & 31 & 30 \\
\hline No & 67 & 65 \\
\hline Unanswered & 5 & 5 \\
\hline Total & 103 & 100 \\
\hline
\end{tabular}

From the above table it is shown that $65 \%$ respondent do their work willingly.

Table No 17: Respondent opinion about the happiness of their work.

\begin{tabular}{|l|l|l|}
\hline & Frequency & Percent \\
\hline Yes & 5 & 5 \\
\hline No & 40 & 39 \\
\hline Sometimes & 58 & 56 \\
\hline Total & 103 & 100 \\
\hline
\end{tabular}

From the above table 56\% workers are happy sometimes to do their work and 39\% are not happy with their work.

Table No 18: Opinion about safety materials available there

\begin{tabular}{|l|l|l|}
\hline \multicolumn{1}{|l|}{ Frequency } & Percent \\
\hline Yes & 15 & 15 \\
\hline \multicolumn{2}{|c|}{ www.iosrjournals.org } & $24 \mid$ Page
\end{tabular}


Causes and Consequences of Child work in Brick Field: A Study on the Selected Brick Field in Char Bhadrasan under Faridpur District.

\begin{tabular}{|l|l|l|}
\hline No & 88 & 85 \\
\hline Total & 103 & 100 \\
\hline
\end{tabular}

At above table shows that $85 \%$ respondent state that there is no any safety material when they work.

Table No 19: Whether they use safety materials or not.

\begin{tabular}{|l|l|l|}
\hline & Frequency & Percent \\
\hline No & 93 & 90 \\
\hline Sometimes & 10 & 10 \\
\hline Total & 103 & 100 \\
\hline
\end{tabular}

Above table shows $10 \%$ respondents use safety materials during their work $.90 \%$ don't use.

Table No 20: Whether they face any injuries during their work.

\begin{tabular}{|l|l|l|}
\hline & Frequency & Percent \\
\hline Yes & 74 & 72 \\
\hline No & 24 & 23 \\
\hline Unanswered & 5 & 5 \\
\hline Total & 103 & 100 \\
\hline
\end{tabular}

From the above table shows $72 \%$ face injuries during their work. Where 5\% respondents don't answer.

Table No 21: Types of injuries did them face.

\begin{tabular}{|l|l|l|}
\hline & Frequency & Percent \\
\hline Minor injuries & 64 & 62 \\
\hline Medium injuries & 15 & 15 \\
\hline Unanswered & 24 & 23 \\
\hline Total & 103 & 100 \\
\hline
\end{tabular}

Above table shows $62 \%$ respondent face minor injuries during their work and $15 \%$ face medium injuries.

Table No 22: Opinion towards the satisfaction of the child labour about the working environment.

\begin{tabular}{|l|l|l|}
\hline & Frequency & Percent \\
\hline Vary satisfactory & 5 & 5 \\
\hline Satisfactory & 26 & 25 \\
\hline Not satisfactory & 67 & 65 \\
\hline Unanswered & 5 & 5 \\
\hline Total & 103 & 100 \\
\hline
\end{tabular}

Above table shows $65 \%$ respondent are not satisfied with their work.

Table No 23: Whether they suffer any disease last six months

\begin{tabular}{|l|l|l|}
\hline & Frequency & Percent \\
\hline Yes & 100 & 97 \\
\hline No & 3 & 3 \\
\hline Total & 103 & 100 \\
\hline
\end{tabular}

From the above table shows $97 \%$ respondent suffer from any disease since last six month.

Table No 24: Types of disease that they faced.

\begin{tabular}{|l|l|l|}
\hline & Frequency & Percent \\
\hline Breathing problem & 18 & 18 \\
\hline Skin disease & 3 & 3 \\
\hline Cold and fever & 59 & 57 \\
\hline Cough & 13 & 13 \\
\hline Others & 10 & 10 \\
\hline Total & 103 & 100 \\
\hline
\end{tabular}

From the above table shows $57 \%$ worker suffer from cold and fever \& $3 \%$ suffer from skin disease.

Table No 25: opinion towards whether their job causes their illness or not.

\begin{tabular}{|l|l|l|}
\hline & Frequency & Percent \\
\hline Yes & 57 & 55 \\
\hline No & 10 & 9 \\
\hline Sometimes & 36 & 35 \\
\hline Total & 103 & 100 \\
\hline
\end{tabular}

It is evident from the above table that 55\% respondent state that their work is caused for their disease.

Table No 26: Respondent profile of facing any torture.

\begin{tabular}{|l|l|l|}
\hline & Frequency & Percent \\
\hline Yes & 36 & 35 \\
\hline
\end{tabular}


Causes and Consequences of Child work in Brick Field: A Study on the Selected Brick Field in Char Bhadrasan under Faridpur District.

\begin{tabular}{|l|l|l|}
\hline No & 10 & 10 \\
\hline Sometimes & 57 & 55 \\
\hline Total & 103 & 100 \\
\hline
\end{tabular}

It is evident from the above table 55\% worker give opinion that sometimes they face torture and $35 \%$ face torture and $35 \%$ face torture regularly.

Table No 27: Types of torture that they faced.

\begin{tabular}{|l|l|l|}
\hline & Frequency & Percent \\
\hline Beating & 11 & 11 \\
\hline Sexual harassment & 18 & 18 \\
\hline Forcing to do hard task & 47 & 46 \\
\hline Others & 17 & 17 \\
\hline Unanswered & 10 & 10 \\
\hline Total & 103 & 100 \\
\hline
\end{tabular}

It is evident from the from the above table $46 \%$ worker are forced to do their work and lowest $11 \%$ respondent face beating.

Table No 28: Opinion of the respondent about who torture them.

\begin{tabular}{|l|l|l|}
\hline & Frequency & Percent \\
\hline Manager & 43 & 42 \\
\hline Co-worker & 21 & 20 \\
\hline Out sides & 03 & 03 \\
\hline Owner & 26 & 25 \\
\hline Total & 93 & 90 \\
\hline Unanswered & 10 & 10 \\
\hline Total & 103 & 100 \\
\hline
\end{tabular}

It is evident from the above table $42 \%$ worker reported the most of the time they are tortured by their manager.

Table No 29: Schooling profile of the respondent.

\begin{tabular}{|l|l|l|}
\hline & Frequency & Percent \\
\hline No & 98 & 95 \\
\hline Unanswered & 05 & 05 \\
\hline Total & 103 & 100 \\
\hline
\end{tabular}

It is evident from the above table 95\% child worker reported that they don't go to school and 5\% respondent doesn't answer.

Table No 30: Respondent profile about the expectation of going school.

\begin{tabular}{|l|l|l|}
\hline & Frequency & Percent \\
\hline Yes & 63 & 61 \\
\hline No & 13 & 13 \\
\hline Sometimes & 22 & 21 \\
\hline Unanswered & 05 & 05 \\
\hline Total & 103 & 100 \\
\hline
\end{tabular}

It is evident from the above table $21 \%$ respondent want to go school sometimes and $13 \%$ don't want to go school and $61 \%$ want to go school. 